\title{
Accounting
}

\section{Determinants influencing the profitability of listed food processing firms in Vietnam}

\author{
Huy Quang Bui ${ }^{a}$, Duc Viet Nguyen a, Do Duc Manh Trana, Phuong Thao Hoang ${ }^{\mathrm{b}}$, Minh Huong \\ Pham $^{\mathrm{b}}$, Manh Dung Tran ${ }^{\mathrm{c}^{*}}$ and Huy Nhuong Buic
}

\begin{abstract}
${ }^{a}$ Advanced Finance 59, National Economics University, Vietnam
${ }^{b}$ Advanced Accounting 59, National Economics University, Vietnam

${ }^{c}$ National Economics University, Vietnam

\begin{tabular}{l}
\hline C H R O N I C L E \\
\hline Article history: \\
Received March 312020 \\
Received in revised format March \\
312020 \\
Accepted April 232020 \\
Available online \\
April 232020 \\
\hline Keywords: \\
Determinants \\
Profitability \\
Food processing firms \\
ROA \\
Vietnam
\end{tabular}

A B S T R A C T

This research is conducted to evaluate the determinants influencing the profitability of the foodprocessing firms in Vietnam. Data was collected from audited financial statements from the foodprocessing firms listed on the Vietnam Stock Exchange from 2012 to 2018 and panel regression model was used in the research (PLS). We selected the methods of testing the model's defects. The testing methods employed in this study were Pearson model, Hausman model, especially the relationship between FEM and REM; Modified Wald Test, Wooldridge test (for autocorrelation in panel data), and lastly Multicollinearity test based on VIF coefficient. The results indicate that Total-Debt-to TotalEquity and Long-term-Debt (TDTELT) had positive influence on profitability. However, Debt Ratio (DR), Short-term Debt Ratio (SDR), Long-term Debt Ratio (LDR) had negative impacts. Fixed Assets to Total Assets (FATA) and Firm size (SIZE) impact Return on Assets (ROA) without statistical significance.
\end{abstract}

\section{Introduction}

The factors influencing the performance of firms have attracted numerous attention and research of scholars in the field of corporate finance for decades. The capital structure of a business reflects the level of debt and equity used to finance its assets. Specifically, the level of using debt will affect the manager's behavior as well as their financial decisions; hence, it tremendously affects the performance of the business (Harris \& Raviv, 1991; Graham \& Harvey, 2001; Myers, 1977, 1984). It is said that considering the impact of factors on profitability ratio is of necessity. By doing so, it not only increases the operational efficiency but also maximizes shareholder assets. In fact, a successful administrator is the one who can determine the optimal capital structure by minimizing the financial cost of the company thereby maximizing the profits. It can be inferred that the capital structure tremendously affects the performance of the firms. In the past 10 years, the food processing industry has shown remarkably its movement towards modernization and industrialization. This sector is predicted to give priority to Vietnam's growth with vision towards 2030. Thanks to preferential policies which revolve around technologies, this industry possesses huge potentials to capture the majority of the market. Meanwhile, prior studies about the impact of determinants upon the profitability of listed firms on the Vietnam Stock Exchange have not been looked into much. Understanding about

* Corresponding author

E-mail address: manhdung@ktpt.edu.vn (M. D. Tran) 
determinants influencing firms' profitability is a key to give the shareholders or investors better insights on whether the amount of capital they spend in a firm will gain returns or losses; thus, they can limit risks. Therefore, the implementation of general research on the determinants influencing the profitability of listed food processing firms in Vietnam is of necessity.

\section{Research hypotheses}

From the viewpoint of a firm management, we focus on the determinants influencing the profitability of listed food processing firms.

\section{Debt ratio $(D R)$}

The debt ratio illustrates the level of leverage in one firm. To simplify, this ratio evaluates the amount of assets which a firm must take into consideration to sell for the sake of paying all the liabilities off. In the studies of Kester (1986), a relatively negative relationship between Debt ratio and Profitability has been found. To determine the influence of DR on the profitability of listed food processing firm through Vietnam Stock Exchange, a hypothesis is designed as:

H1: Debt ratio has an influence on the profitability of listed food processing firms.

Short-term Debt to Total Assests (SDR)

The short term debt to total assets (SDR) shows the probability that a firm is capable of proving payments to the liabilities which are not paid in short term. According to Abor (2005), there exists a positive relationship associated with SDR and firm's profitability. To determine the influence of SDR on the profitability of listed food processing firms, a hypothesis is designed as follow:

H2: Short-term Debt to Total Assets influences the profitability of listed food processing firms.

Long-term debt ratio (LDR)

The long-term debt ratio indicates a firm's long-term financial position, especially its ability to meet the financial obligations for outstanding debts also included. Long-term debt ratio influences on firms' performance of the firm. In order to check the significance of long-term debt ratio on firms' performance, we design the hypothesis as:

H3: Long-term debt ratio has an impact on the profitability of listed food processing firms.

Firm size (SIZE)

Firm size is one of the most important determinants for investors, suppliers and partners. There are studies that demonstrate the relationship between size of the firm and profitability. Serrasqueiro and Nunes (2008) studied the relationship between the size and performance of big and small-scale firms operating in Portugal. They found positive and statistically significant relationship between the size and performance of the firms as a result of the study using the data belonging the years 1999-2003. On the contrary, Shepherd (1972) has found a negative relationship between firm size and profitability. As a result, to show clearly the impact of firm size on profitability, we have a hypothesis as:

H4: Firm size has a relationship with the profitability of listed food processing firms.

GDP growth $(G D P)$

GDP is considered as one of the most important indicators to define the total number of added values, generated by the whole business units within a certain country. By this point of view, the effect of GDP to the firms' profitability is certainly described. Decreasing in GDP has a negative impact on consumer purchasing power; furthermore, it can diminish the demand products which ultimately can reduce the profitability of the firm (Tandelilin, 2010). To check the significance of GDP growth on the profitability of listed firms, we design the hypothesis as:

H5: GDP growth has an impact on the profitability of listed food processing firms.

\section{Years of operation (AGE)}

The operating time of a firm is defined as the number of years that the firms have incorporated. Usually, the older and longstanding firms are likely to attain more complex, optimal profitability than the new ones. However, there have been many firms proved the reverse theories, which caused the negative correlation between years of operation and profitability index. So, we design a hypothesis as:

H6: Firm duration has a relationship with the profitability of food processing firms. 
Inflation at medium level probably boosts the economy as it encourages firms to promote investment so as to raise productivity and improve products' quality. In contrast, stagflation may cause the economy's degradability that leads to the bankruptcy of firms and the recession of some certain aspects of economy such as finance. There are many other cases showing that inflation rates positively correlated with profit-generating ability, so that the hypothesis should be:

H7: Inflation impacts on the profitability of food processing firms.

Fixed Assets to Total Assets (FATA)

Fixed Assets to Total Assets can be considered as a tool to help investors as well as the firms assess the stability of investing in fixed assets. As analyzed previously, the smaller the fixed assets to total assets coefficient is, the higher the level of safety will be. In order to determine the extent to which short term debt influences firms' performance, we design the hypothesis as:

H8: FATA has an impact on the profitability of listed food processing firms.

Total debts per sum of total equity and long-term (TD/TE+LTD)

Total debts per sum of total equity and long-term (TD/TE+LTD) not only helps the investors but also is an effective tool to measure the risk of refinancing. Therefore, in order to clarify the impact of total debt on the sum of total equity and long-term debt on the profitability of listed food processing firms on Vietnam Stock Exchange, we design a hypothesis as:

H9: TD/TE + LTD has an impact on the profitability of listed food processing firms.

\section{Research methodology}

\subsection{Research model}

The research aims to identify the impact of many factors such as debt ratio, short-term debt ratio, long-term debt ratio, fixed asset to total asset, size, years of operation, GDP growth, inflation and TD/(TE+LTD) on profitability of food processing firms. These items are expressed by the return, debt ratio, and others to the profit of listed food processing firms. Therefore, a regression model has been designed that carries the qualified determinants.

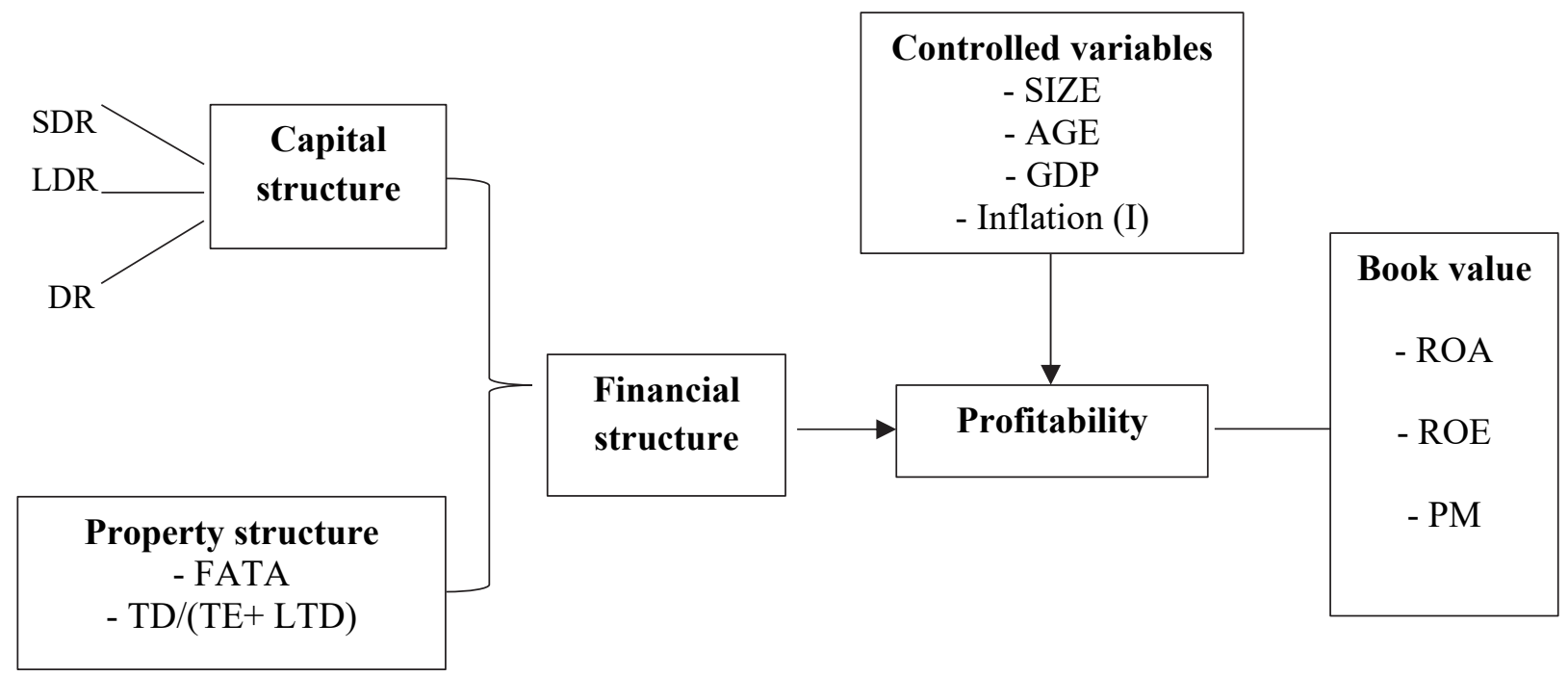

Fig. 1. Research Model

where:

ROA: Return on Assets; ROE: Return on Equity; PM: Profit Margin

DR: Debt Ratio

SDR: Short term to Total Assets 
LDR: Long term Debt to Total Assets

FATA: Fixed Assets to Total Assets

TD/(TE+LTD): Total Debt divided by Total Equity and Long-term Debt

SIZE: Size of firms

AGE: Years of operation

GDP: Economic Growth rate

I: Inflation

\subsection{Data Collection}

In this study, the collected data is mainly a secondary data gathered from audited financial statements (including cash flow statement; financial position statements or balance sheet; comprehensive income statement; and notes to the financial statements) of the listed food processing firms on Vietnam Stock Exchange (including Ho Chi Minh City Stock Exchange (HSX) and Hanoi Stock Exchange (HNX)) for a period of 7 years from 2012 to 2018. Besides, the study also refers the information from websites, some management statements of cophieu68.vn, finance.vietstock.com, hnx.com, cafef.vn, stockbiz.com, ect. As a result, we chose 35 listed food processing firms on the stock market, corresponding to 245 observations. The data was then put in worksheets of Microsoft Excel before transferring to Stata14 for processing and analyzing. Some basic information of revenue of listed food processing firms is presented in Table 1, below:

Table 1

Revenue in the Multiyear Dataset

\begin{tabular}{|c|c|c|c|c|c|c|c|c|c|c|}
\hline \multirow{2}{*}{ Revenue } & \multicolumn{2}{|c|}{2012} & \multicolumn{2}{|c|}{2015} & \multicolumn{2}{|c|}{2016} & \multicolumn{2}{|c|}{2017} & \multicolumn{2}{|c|}{2018} \\
\hline & No. & $\%$ & No. & $\%$ & No. & $\%$ & No. & $\%$ & No. & $\%$ \\
\hline Revenue $>4,847,159$ & 5 & 14.29 & 9 & 25.71 & 8 & 22.86 & 9 & 25.71 & 9 & 25.71 \\
\hline Revenue $<4,847,159$ & 30 & 85.71 & 26 & 74.28 & 27 & 77.14 & 26 & 74.28 & 26 & 74.28 \\
\hline Total & 35 & 100 & 35 & 100 & 35 & 100 & 35 & 100 & 35 & 100 \\
\hline
\end{tabular}

Data in Table 1 demonstrates that from 2012 and 2013, the size of more than $82 \%$ of food processing firms is smaller than the average industry size. The main reason is the characteristics of domestic consumption. The market is dominated by large firms (beverages; animal and vegetable oil productions; milk and dairy product processing) due to the large initial investment costs and the high competition in this field. Another reason is that these firms have long operating time (AGE), a great deal of experience and they grasp the needs of partners and clients. At the point when there exists a large revenue with a stable financial performance, the firm can maintain a reasonable profit margin and debt ratio (DR). Because of their size, consumer's confidence in these firms is greater than that of the small firms. Besides, the market is also dominated by private traders (Meat and meat products processing and preserving; seafood and fishery products processing and preserving; vegetables and fruits processing and preserving) as most consumers still have the habit of buying fresh meat and vegetables at traditional markets instead of buying weekly at supermarkets. In the period of 2014-2018, the difference in revenue over the years has been reduced. The number of food processing firms' size which is smaller than the average industry size has decreased approximated $75 \%$. The reason is that the market has gradually become more stable after the economy recession. Consumer's confidence in new and small businesses has also gradually increased over time. Although the disparity is still very large due to the industry characteristics, these are also good figures for the food processing industry in Vietnam.

Table 2

Descriptive Statistics of Listed Food Processing Firms

\begin{tabular}{|c|c|c|c|c|c|}
\hline Variables & Mean & Median & Max & Min & Std. Dev. \\
\hline $\mathrm{ROA}$ & 0.102275 & 0.086472 & 0.7837 & -0.436211 & 0.091106 \\
\hline ROE & 0.193462 & 0.160845 & 2.91825 & -0.53093 & 0.219918 \\
\hline PM & 0.081801 & 0.067136 & 1.678176 & -2.026303 & 0.184154 \\
\hline DR & 0.444152 & 0.406298 & 1.149477 & 0.09738 & 0.181348 \\
\hline SDR & 0.389073 & 0.348799 & 1.143964 & 0.087057 & 0.172274 \\
\hline LDR & 0.055077 & 0.01727 & 0.506356 & 0 & 0.090942 \\
\hline FATA & 0.373986 & 0.337104 & 0.90742 & 0.000146 & 0.204247 \\
\hline TD_TE_LT & 0.867163 & 0.630362 & 4.362314 & -7.984496 & 0.931402 \\
\hline SIZE & 6.125882 & 5.968966 & 7.720671 & 4.093176 & 0.710375 \\
\hline GDP & 6.204286 & 6.21 & 7.08 & 5.25 & 0.648978 \\
\hline Inflation (I) & 4.51 & 3.54 & 9.09 & 0.88 & 2.45607 \\
\hline AGE & 16.45714 & 16 & 46 & 9 & 5.819977 \\
\hline
\end{tabular}


Table 2 presents values based on software of Stata 14. In particular, these include 6 components: minimum value (Minimum); highest value (Maximum); Average values (Mean), standard deviations (Std. Deviation) and the probability of 35 food processing firms are listed on the Vietnam Stock Exchange in 7 years from 2012 to 2018. As stated in theoretical framework, we calculate Return on Assets (ROA) as a proxy of profitability along with nine determinants influencing the performance of food processing firms. ROA is presented in Table 3.

Table 3

The average ROA in listed food processing firms in 2012-2018

\begin{tabular}{llllllll}
\hline Year & 2012 & 2013 & 2014 & 2015 & 2016 & 2017 & 2018 \\
\hline ROA (average) & 0.114 & 0.098 & 0.092 & 0.125 & 0.093 & 0.093 & 0.101 \\
\hline
\end{tabular}

\subsection{Techniques}

After the data collection step, data screening and putting in the worksheets are conducted. Then, we transfer data in Stata in order to process the model regression analysis together with testing methods of overcoming the defects of the models for concluding hypotheses designed with the case studies of listed food processing firms on Vietnam Stock Exchange. The research sample includes 35 food processing firms listed on the stock market for the period from 2012 to 2018, so the panel least squares model (PLS) is employed. The different testing methods used in this study are Hausman model, especially the relationship between FEM and Pooled OLS; Modified Wald Test, Wooldridge test (for autocorrelation in panel data), and lastly Multicollinearity test based on VIF coefficient and Pearson model.

\section{Results and Discussions}

\section{Pearson correlation coefficient}

First, we will select the Pearson model. By running Pearson correlation coefficient, it shows the correlation relationship between two variables in the model. In Stata using the command "pwcorr", we have Model 1 and 2 showing the correlation between the variables. In particular, while Model 1 describes the correlation coefficients among the variables in the equation, with debt ratio is one of the variables; Model 2 shows the correlation coefficients among the variables, with long-term debt and short-term debt ratios are one of the independent variables. In these two models, correlation coefficients among all variables are different from zero with the exception of inflation age and GDP, the largest correlation values reach 0.327 (Model 1), 0.538 (Model 2). Thus, the variables are correlated with each other. In terms of correlation values, most of the correlations are at medium and low levels except the correlation coefficient between FATA and LDR is quite high. Based on our research, that correlation coefficients are considered high when their value are greater than 0.7 is likely to be multicollinearity. Finally, Age, GDP and Inflation fail to impact on the profitability correlation because the significant level is above $5 \%$.

\section{Model Choice}

We select the most appropriate model of FEM, REM models through Hausman test. The test results are shown in Table 4, below:

Table 4

Hausman test results between REM and FEM models

\begin{tabular}{cccccc}
\hline Model & $\begin{array}{c}\text { Capital structure } \\
\text { variable }\end{array}$ & Dependent variables & ProbChi2(x) & Pro $>$ Chi 2 & $\begin{array}{c}\text { Model (FEM, } \\
\text { REM) }\end{array}$ \\
\hline Model 1a & DR & \multirow{2}{*}{ ROA } & 35.64 & 0.0000 & FEM \\
Model 1b & SDR,LDR & \multirow{2}{*}{ SD } & 18.45 & 0.0024 & FEM \\
\hline
\end{tabular}

The Hausman test results show that all 2 models which are ROA (Return on Assets) using optimal FEM model. After selecting the FEM model, we continue to choose the best model between OLS and FEM through the testing results of the FEM model. Table 5 shows the optimal model selection results.

Table 5

The optimal model selection

\begin{tabular}{|c|c|c|c|c|c|}
\hline Model & $\begin{array}{c}\text { Capital structure } \\
\text { variable }\end{array}$ & $\begin{array}{c}\text { Dependent } \\
\text { variables }\end{array}$ & $F(27,164), F(27,163)$ & Pro $>$ Chi 2 & $\begin{array}{r}\text { Model (FEM, } \\
\text { REM) }\end{array}$ \\
\hline Model 1a & $\mathrm{DR}$ & \multirow{2}{*}{ ROA } & 9.97 & 0.0000 & FEM \\
\hline Model 1b & SDR, LDR & & 9.77 & 0.0024 & FEM \\
\hline
\end{tabular}

Thus, in all equations, FEM regression model is the most suitable compared to two models OLS and REM. So we continue to examine the FEM model. 


\section{Multicollinearity test}

Multicollinearity is the event of independent variables in a model that are related to each other. Generally, a perfect multicollinearity cannot be estimated while an imperfect multicollinearity may make the linear independent variables lose its meaning in the model or may be led to a sign of regression error. Studies often use two methods to detect multicollinearity: the correlation coefficient method and the variance inflated factor (VIF), if the VIF factor is less than 5, the issue of collinearity is less likely to occur.

Table 6

Multicollinearity Testing in the Regression Model of ROA

\begin{tabular}{lcccc}
\hline & \multicolumn{2}{c}{ Equation 1a } & \multicolumn{2}{c}{ Equation 1b } \\
\hline DR & VIF & 1/VIF & VIF & $1 /$ VIF \\
SDR & 1.95 & 0.649351 & 1.94 & 0.515464 \\
LDR & & & 1.75 & 0.571429 \\
FATA & & & 1.65 & 0.606061 \\
TDTELT & 1.18 & 0.847457 & 1.51 & 0.662252 \\
SIZE & 1.50 & 0.666667 & 1.25 & 0.800000 \\
\hline Mean $\boldsymbol{V I F}$ & 1.22 & & 0.819672 & \\
\hline
\end{tabular}

For both pairs of regression equations, the VIF coefficient is less than 5, there is no multicollinearity issue in this situation.

Heteroscedasticity test

Heteroscedasticity testing using Modified Wald test is conducted and presented in Table 7.

Table 7

Heteroscedasticity Testing for ROA

\begin{tabular}{cccccc}
\hline Model & $\begin{array}{c}\text { Capital structure } \\
\text { variable }\end{array}$ & $\begin{array}{c}\text { Dependent } \\
\text { variable }\end{array}$ & $\begin{array}{c}\text { ProbChi2 } \\
\mathbf{( 2 8 )}\end{array}$ & Pro>Chi 2 & Results \\
\hline Model 1a & DR & & 2188.27 & 0.0000 & Occur heteroscedasticity \\
Model 1b & SDR, LDR & ROA & 2880.88 & 0.0000 & Occur heteroscedasticity \\
\hline
\end{tabular}

Thus, the test results show that both regression models occur heteroscedasticity. When the models occur heteroscedasticity, the estimation falsifies the standard errors, thereby increasing the statistical value $\mathrm{t}$ and $\mathrm{F}$ leading to inaccurate conclusions.

Autocorrelation testing

To check for the autocorrelation, we use Wooldridge test method. The test is conducted and presented in the Table as below:

Table 8

Autocorrelation Testing for ROA

\begin{tabular}{cccccc}
\hline Model & $\begin{array}{c}\text { Capital structure } \\
\text { variable }\end{array}$ & $\begin{array}{c}\text { Dependent } \\
\text { variables }\end{array}$ & $\mathbf{F ( 1 , 3 4 )}$ & Pro>F & Results \\
\hline Model 1a & DR & & 0.1243 & 0.1587 & No autocorrelation \\
Model 1b & SDR, LDR & ROA & 0.0458 & 0.1488 & No autocorrelation \\
\hline
\end{tabular}

From the results of data processing, the obtained $\mathrm{F}(1,34)$ is less than Prob $>\mathrm{F}$. Hence, there is no autocorrelation issue within the model in general.

\section{Table 9}

Summary of defects of regression models

\begin{tabular}{llccc}
\hline Model & Capital structure variable & $\begin{array}{c}\text { Dependent } \\
\text { variable }\end{array}$ & Multicollinearity test & Heteroskedasticity test \\
\hline Model 1a & DR & ROA & $\sqrt{ }$ \\
Model 1b & SDR, LDR & $\sqrt{ }$ & $\sqrt{ }$ \\
\hline
\end{tabular}


From linear regression analysis results through three models with dependent variables of ROA as profitability proxy, some conclusions regarding the impact of determinants on the profitability of listed food processing firms on the Vietnam Stock Exchange as shown below:

\section{Debt Ratio (DR)}

DR has a negative impact on Return On Assets (ROA). These findings are the same with the Khan (2012) study in Pakistan which has shown a negative correlation between profitability and debt ratio. To be more precise, since the debt ratio increases, the firms would encounter a gradual loss in the financial autonomy.

\section{Short-term Debt Ratio (SDR)}

SDR has a negative effect on all three dependent variables of ROA. In the content of the research topic, Short-term Debt Ratio is measured by the rate of short-term debt on total assets. Therefore, a decline in financial performance is due to a rise in the ratio of short-term debt to total assets. It is recommended that the firms reduce the usage of short-term debts in financing operations so as to improve their financial performance. These findings have the same results with the study of Dawar (2014) in India about the impact of SDR on ROA.

\section{Long-term Debt Ratio (LDR)}

LDR has a negative impact on Return On Assets (ROA). This links with the study of Dawar (2014) with same results about relationship between long-term debt ratio and profitability. Long-term-debt-to-total-asset ratio is a solvency or coverage ratio which calculates the leverage of a business by comparing total debt to assets. In other terms, it calculates the amount of assets that a company needs to liquidate in order to pay on off its long-term debts. A higher percentage ratio means that the company is more leveraged and owns less of the assets on the balance sheet.

\section{Total Debt to Total Equity and Long Term Debt (TDTELT)}

TDTELT has a positive influence on dependent variables of ROA. TDTELT is a measurement of a firm's financial leverage. It is calculated by taking the firm's interest-bearing debt, both short and long-term liabilities and dividing it by the long-term debt plus shareholders' equity. TDTELT gives analysts and investors a better idea of a firm's capital structure and whether or not the company is a suitable investment. All else being equal, the higher the TDTELT ratio, the riskier the firm to be invested in. This finding has the same results with the research of Nguyen (2016) in Vietnam.

Fixed Assets to Total Assets (FATA) impacts on ROA but it has not been statistically significant on them.

\section{Adjusted Model}

To overcome the above defects of the model, we employ different regression methods, depending on the type of defects. As for models with dependent variable of Return on Assets (ROA) that heteroscedasticity exists, this error would be fixed by adding the "robust" command to the end of the FEM regression statement. The results are obtained as shown in Table 10, below:

\section{Table 10}

Estimated Results of Regression Model ROA

\begin{tabular}{|c|c|c|}
\hline & Equation 1a & Eauation 1b \\
\hline $\mathrm{DR}$ & $\begin{array}{c}-0.266642 \\
(-9.18)\end{array}$ & \\
\hline SDR & & $\begin{array}{c}-0.2575729 \\
(-8.30)\end{array}$ \\
\hline LDR & & $\begin{array}{c}-0.2916419 \\
(-6.28)\end{array}$ \\
\hline FATA & $\begin{array}{c}-0.1233716 \\
(-1.94)\end{array}$ & $\begin{array}{c}-0.1175987 \\
(-1.92)\end{array}$ \\
\hline TDTELT & $\begin{array}{l}0.0245583 \\
(6.98)\end{array}$ & $\begin{array}{l}0.0245643 \\
(6.37)\end{array}$ \\
\hline SIZE & $\begin{array}{c}0.0055286 \\
(0.41)\end{array}$ & $\begin{array}{c}0.0050401 \\
(0.37)\end{array}$ \\
\hline cons & $\begin{array}{l}0.21168 \\
(2.06)\end{array}$ & $\begin{array}{l}0.2103563 \\
(2.04)\end{array}$ \\
\hline$\underline{\mathrm{N}}$ & 245 & 245 \\
\hline t statistics in & parenthese $* \mathrm{p}<0.05 . * *$ & $0.01 . * * * \mathrm{p}<0.001$ \\
\hline
\end{tabular}

According to Table 10, variables of Debt ratio (DR), Short-term debt ratio (SDR), Long-term debt ratio (LDR) have the negative impact with Return on Assets (ROA). On the other hand, TDTELT has a positive impact on ROA. In addition, FATA and SIZE impact 
on ROA but have not statistically significant on it.

Based on the regression results presented in Table 10, we give regression equations of the following form:

$$
\begin{aligned}
& R O A=0.21168-0.266642 \times D R-0.1233716 \times F A T A+0.0245583 \times T D T E L T+0.050401 \times \text { SIZE }+e \\
& R O A=0.2103563-0.2575729 \times S D R-0.2916419 \times L D R-0.1175987 \times F A T A+0.0245643 \times \text { TDTELT }+0.050401 \\
& \times S I Z E+e
\end{aligned}
$$

Eq. (1) means:

$+\beta 1=-0.266642$ indicates that when the DR increases by 1 time, in the condition that other factors remained constant, the average ROA decreases by 0.266642 times.

$+\beta 2=-0.1233716$ reveals that when the FATA increases 1 time, in the condition that other factors remain unchanged, ROA will decrease by 0.1233716 times.

$+\beta 3=0.0245583$ shows that when TDTELT increases by 1 time, under other conditions, the average ROA increases by 0.0245583 times.

$+\beta 4=0.0055286$ illustrates that when SIZE increases by 1 time, under other conditions, the average ROA increases by 0.0055286 times.

Eq. (2) means:

$+\beta 1=-0.2575729$ indicates that when the SDR increases by 1 time, in the condition that other factors remained constant, the average ROA decreases by 0.2575729 times.

$+\beta 2=-0.2916419$ indicates that when the LDR increases by 1 time, in the condition that other factors remained constant, the average ROA decreases by 0.2916419 times.

$+\beta 3=-0.1175987$ reveals that when the FATA increases 1 time, in the condition that other factors remain unchanged, ROA will decrease by 0.1175987 times.

$+\beta 4=0.0245643$ shows that when TDTELT increases by 1 time, under other conditions, the average ROA increases by 0.0245643 times.

$+\beta 5=0.0050401$ illustrates that when SIZE increases by 1 time, under other conditions, the average ROA increases by 0.0050401 times.

\section{Conclusion}

This study has been conducted to investigate the impact levels of determinants including capital structure on profitability ratios of food processing firms listed on the Vietnam Stock Exchange. Data were collected from financial statements of 35 listed food processing firms for the period from 2012 to 2018 on Vietnam Stock Exchange. Through analyzing the three-adjustment model of Return on Assets (ROA), we see that three variables of AGE, GDP growth, and Inflation did not have impact on profitability (proxied by ROA). DR, SDR and LDR have maintained negative impacts on profitability. In contrast, TDTELT have had positive impacts on the profitability. FATA and SIZE impacted Return on Assets (ROA) without statistical significance. Based on the findings, some suggestions are given to listed food processing firms to establish a financial structure to improve the profitability, so listed firms need to take the following actions such as (i) recognize the importance of financial structure that directly affects business performance and business risk. For capital structure, indicators such as Debt Ratio (DR), Short-term debt ratio (SDR) all negatively affect all variables reflecting profitability. Therefore, establishing a reasonable financial structure is a prerequisite to increase the profitability in the business. (ii) In addition to the financial structure, many factors affect profitability such as SIZE, GDP, and AGE. Thus, firms need to pay attention to the impact of these determinants on profitability, thereby taking measures to improvise promptly. On the side of Vietnam Food Association (VFA), the organization is of importance in managing and supporting the food processing firms in Vietnam. In particular, VFA is established under Decision No.727/KDDN-QD on November 13, 1989 by the Ministry of Industry and Trade. Vietnam Food Association is a non-profit and non-governmental organization. The organization was established to help individuals, organizations and businesses operating in food production, food processing, food trading and agricultural products in Vietnam. Vietnam Food Association has a great responsibility to support food processing company which are giving proposals, advice and suggestions to state agencies on inappropriate regimes and policies which is detrimental to construction enterprises and adversely affecting the general development of society. VFA bridges the gap between firms by building cooperation, association and exchange of experience, Science \& Technology in operation for the purpose of improving business efficiency. Also, VFA becomes a focal 
point to recognize the difficulties of listed firms and advising the government on programs to support business development and increase production value. On the side of Stock Exchanges in Vietnam (Stock Exchange of Hanoi: HNX; and Stock Exchange of Ho Chi Minh City: HOSE), they play a great role in managing, encouraging listed food processing firms to improve. Therefore, the Stock Exchange should create conditions for businesses in the following aspects which are merging HOSE and HNX in order to facilitate listed firms to have the same operating environment. Also, it strengthens the monitoring function for listed firms, create strong sanctions against companies that intentionally cheat information. Based on the data of listed food firms, the Stock Exchange should calculate more than the average economic indicators of the industry, from which businesses can compare and position themselves.

\section{References}

Abor, J. (2005). The effect of capital structure on profitability: an empirical analysis of listed firms in Ghana. Journal of Risk Finance, 6, 438-447.

Dawar, V. (2014). Agency Theory, Capital Structure and Firm Performance: Some Indian Evidence. Managerial Finance, $12(40), 1190-1206$.

Graham, J.R., \& Harvey, C.R. (2001). The theory and practice of corporate finance: Evidence from the field. Journal of Financial Economics, 60, 187-243.

Harris, M., \& Raviv, A. (1991). The theory of Capital Structure. Journal of Finance, 46, 297-355.

Kester, W. (1986). Capital and ownership structure: a comparison of United States and Japanese manufacturing corporations. Financial Management, 15, 5-16.

Khan, A.G. (2012). The relationship of capital Structure decisions with firm performance: A study of the engineering sector of Pakistan. International Journal of Accounting and Financial Reporting, 2(1), 245-262.

Myers, S.C. (1977). Determinants of Corporate Borrowing. Journal of Financial Economics, 5, 147-175.

Myers, S.C. (1984). The capital structure puzzle. Journal of Finance, 39, 575-592.

Nguyen, H.C. (2016). Capital Structure and Firm's Performance: Evidence from HOSE. Master Thesis. Berlin School of Economics and Law.

Serrasqueiro, Z., \& Nunes, P. (2008). Performance and size: empirical evidence from Portuguese SMEs. Small Business Economics, 31(2), 195-217.

Shepherd, W.G. (1972). The elements of market structure. Review of Economics and Statistics, 54, 25-35.

Tandelilin, E. (2010). Portofolio dan Investasi Teori dan Aplikasi (Edisi Pert). Yogyakarta: Kanisius. Indonesia.

\section{Appendix No. 1 ROA model 1}

(command: xtreg ROA, DR, FATA, TDTELT, SIZE, fe)

\begin{tabular}{lcccccc}
\hline ROA & Coef. & Std.Err. & T & P $>|\mathbf{t}|$ & \multicolumn{2}{c}{ 95\% Conf.Interval } \\
\hline DR & -0.263622 & 0.0263851 & -9.98 & 0.000 & -0.3154605 & -0.2112639 \\
FATA & -0.0659737 & 0.0362825 & -1.82 & 0.071 & -0.1376148 & 0.0056673 \\
TDTELT & -0.0234043 & 0.003601 & 6.5 & 0.000 & 0.016294 & 0.0305146 \\
SIZE & -0.0285042 & 0.0147673 & 1.93 & 0.055 & -0.0006543 & 0.0576628 \\
Cons & 0.0523894 & 0.0891142 & 0.59 & 0.557 & -0.1235697 & 0.2283486 \\
\hline
\end{tabular}

\begin{tabular}{|ll|}
\hline Sigma u & 0.05004512 \\
Sigma e & 0.03887115 \\
Rho & 0.6237147 \\
\hline
\end{tabular}

F test that all $u_{i}=0: F(27,164)=9.97$

Prob $>$ F $=0.0000$

(command: hausman fem rem)

Coefficient

\begin{tabular}{lcccc}
\hline & $(\mathrm{b})$ & $(\mathrm{B})$ & $(\mathrm{b}-\mathrm{B})$ & $\mathrm{sqrt}\left(\operatorname{diag}\left(\mathrm{V} \_\mathrm{b}-\mathrm{V}\right.\right.$ B $\left.)\right)$ \\
\hline DR & Fem & rem & Difference & S.E. \\
FATA & -0.2633622 & -0.28411 & 0.0207478 & 0.011812 \\
TDTELT & -0.0659737 & -0.030132 & -0.0358417 & \\
SIZE & 0.0234043 & 0.0235507 & -0.0001465 & 0.0104153 \\
\hline
\end{tabular}

$\mathrm{b}=$ consistent under Ho and Ha; obtained from xtreg

$\mathrm{B}=$ inconsistent under $\mathrm{Ha}$, efficient under Ho; obtained from xtreg

Test: Ho: difference in coefficients not systematic

Chi2(4) $=(b-B)^{\prime}\left[\left(V_{-} \text {b-V_B }\right)^{\wedge}(-1)\right](b-B)=35.64$ 
450

Prob $>$ chi2 $=0.0000\left(V_{-} b-V_{-} B\right.$ is not positive definite $)$

(command: xttest3)

Modified Wald test for groupwise heteroskedasticity

in fixed effect regression model:

H0: $\operatorname{sigma}(\mathrm{i})^{\wedge} 2=\operatorname{sigma}^{\wedge} 2$ for all $\mathrm{i}$

$\operatorname{chi} 2(28)=2188.27$

Prob $>$ chi $2=0.0000$

(command: xtserial ROA, DR, FATA, TDTELT, SIZE)

Wooldridge test for autocorrelation in panel data

H0: no first order autocorrelation

$\mathrm{F}(1,34)=0.1243$

Prob $>F=0.1587$

(command: collin ROA, DR, FATA, TDTELT, SIZE)

\begin{tabular}{lcccc}
\hline Variables & VIF & SORT VIF & Tolerance & R-sauared \\
\hline ROA & 1.54 & 1.24 & 0.6511 & 0.3489 \\
DR & 1.95 & 1.40 & 0.5137 & 0.4863 \\
FATA & 1.18 & 1.09 & 0.8447 & 0.1533 \\
TDTELT & 1.50 & 1.23 & 0.6653 & 0.3347 \\
SIZE & 1.22 & 1.10 & 0.8213 & 0.1787 \\
\hline
\end{tabular}

\section{Mean VIF 1.48}

\begin{tabular}{ccc}
\hline & Eigenval & Index \\
\hline 1 & 4.8212 & 1.0000 \\
2 & 0.6058 & 2.8211 \\
3 & 0.3787 & 3.5679 \\
4 & 0.1446 & 5.7741 \\
5 & 0.0438 & 10.4952 \\
6 & 0.0059 & 28.5072 \\
\hline
\end{tabular}

Condition Number $\quad 28.5072$

Eigenvalues \& Cond Index computed from scaled raw sscp (w/ intercept)

Det(correlation matrix) $\quad 0.4084$

Appendix No. 2: ROA model 2

(command: xtreg ROA SDR LDR FATA TDTELT SIZE, fe)

\begin{tabular}{|c|c|c|c|c|c|c|}
\hline ROA & Coef. & Std.Err. & $\mathbf{t}$ & $\mathbf{P}>|\mathbf{t}|$ & \multicolumn{2}{|c|}{$[95 \%$ Conf.Interval] } \\
\hline SDR & -0.2593568 & 0.030217 & -8.58 & 0.000 & -0.3190241 & -0.1996896 \\
\hline LDR & -0.2750795 & 0.0501909 & -5.48 & 0.000 & -0.3741877 & -0.175913 \\
\hline FATA & -0.0628423 & 0.0381232 & -1.65 & 0.101 & -0.1381212 & 0.0124366 \\
\hline TDTELT & 0.0234813 & 0.003622 & 6.48 & 0.000 & 0.0163293 & 0.0306333 \\
\hline SIZE & 0.0278798 & 0.0149824 & 1.86 & 0.065 & -0.0017048 & 0.0574644 \\
\hline Cons & 0.0539381 & 0.0895436 & 0.60 & 0.548 & -0.1228769 & 0.2307532 \\
\hline
\end{tabular}

\begin{tabular}{|cc|}
\hline sigma $\mathbf{u}$ & 0.0501442 \\
sigma & 0.0389808 \\
Rho & 0.62332103 \\
\hline
\end{tabular}

F test that all $u_{-} i=0: F(27,163)=9.77 \quad$ Prob $>F=0.0000$

(Command: hausman fem rem)

\begin{tabular}{|c|c|c|c|c|}
\hline & (b) & (B) & (b-B) & $\operatorname{sart}(\operatorname{diag}(\mathrm{V} \quad b-\mathrm{V} \quad \mathrm{B}))$ \\
\hline & fem & rem & Difference & S.E. \\
\hline SDR & -.2593568 & .2719626 & .0126057 & \\
\hline LDR & -.2750795 & -.3275023 & .0524228 & \\
\hline FATA & -.0628423 & -.0154806 & -.0473617 & .0093367 \\
\hline TDTELT & -.0234813 & -.0233672 & .0001141 & \\
\hline
\end{tabular}


$\mathrm{b}=$ consistent under Ho and Ha; obtained from xtreg

$\mathrm{B}=$ inconsistent under Ha, efficient under Ho; obtained from xtreg

Test: Ho: difference in coefficients not systematic

$\operatorname{chi} 2(5)=(b-B)^{\prime}\left[\left(V \_b-V \_B\right)^{\wedge}(-1)\right](b-B)=\quad 18.45$ Prob $>$ chi2 $=0.0024$

(command:xttest3)

Modified Wald test for groupwise heteroskedasticity in fixed effect regression model:

H0: $\operatorname{sigma}(\mathrm{i})^{\wedge} 2=\operatorname{sigma}^{\wedge} 2$ for all $\mathrm{i}$

$\operatorname{chi} 2(28)=2180.88 ;$ Prob $>$ chi $2=0.0000$

(command: xtserial ROA SDR LDR FATA TDTELT SIZE)

Wooldridge test for autocorrelation in panel data

$\mathrm{H} 0$ : no first order autocorrelation
$\mathrm{F}(1,34)=0.0458$
Prob $>\mathrm{F}=$
0.1587

(Command: collin ROA SDR LDR FATA TDTELT SIZE)

Collinearity Diagnostics

\begin{tabular}{ccccc}
\hline & & SQRT & & R- \\
\cline { 2 - 5 } Variable & VIF & VIF & Tolerance & Squared \\
\hline ROA & 1.57 & 1.25 & 0.6375 & 0.3625 \\
SDR & 1.94 & 1.39 & 0.5148 & 0.4852 \\
LDR & 1.75 & 1.32 & 0.5702 & 0.4298 \\
FATA & 1.65 & 1.28 & 0.6057 & 0.3943 \\
TDTELT & 1.51 & 1.23 & 0.7970 & 0.3374 \\
SIZE & 1.25 & 1.12 & & 0.2030 \\
\hline
\end{tabular}

Mean VIF 1.61

\begin{tabular}{lcc}
\hline & Eigenval & Index \\
\hline 1 & 5.1170 & 1.0000 \\
2 & 0.7993 & 2.5301 \\
3 & 0.6167 & 2.8806 \\
4 & 0.3077 & 4.0783 \\
5 & 0.1090 & 6.8512 \\
6 & 0.0447 & 10.6989 \\
7 & 0.0056 & 30.2761 \\
\hline
\end{tabular}

Condition Number $\quad 30.2761$

Eigenvalues \& Cond Index computed from scaled raw sscp (w/ intercept)

Det(correlation matrix) $\quad 0.2476$

\section{(Command:. xtreg ROA DR FATA TDTELT SIZE, fe robust)}

Fixed-effects (within) regression

Group variable: firm1

R-sq:

within $=0.5681$

between $=0.5747$

overall $=0.5659$

$\mathrm{F}(4,27)=238.26$

corr(u_i, Xb) $=0.1454$

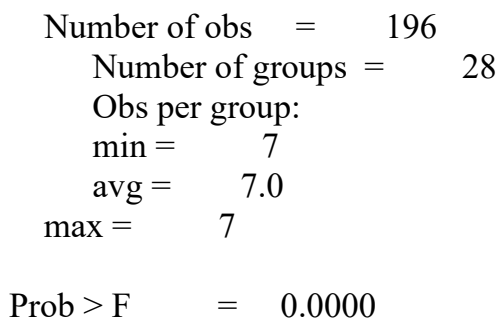


(Std. Err. adjusted for 28 clusters in firm1)

\begin{tabular}{|c|c|c|c|c|c|c|}
\hline \multicolumn{7}{|c|}{ Robust } \\
\hline ROA & Coef. & Std. Err. & $\mathrm{t}$ & $\mathrm{P}>|\mathrm{t}|$ & {$[95 \%$ Cor } & \\
\hline DR & -.266642 & .0290556 & -9.18 & 0.000 & -.3256901 & -.2075939 \\
\hline FATA & -.1233716 & .0630774 & -1.96 & 0.059 & -.2515603 & .004817 \\
\hline TDTELT & .0245583 & .0035209 & 6.98 & 0.000 & .017403 & .0317136 \\
\hline SIZE & .0055286 & .0135332 & 0.41 & 0.685 & -.0219741 & .0330314 \\
\hline cons & .21168 & .1029421 & 2.06 & 0.047 & .0024765 & .4208836 \\
\hline sigma_u & & & & 397261 & & \\
\hline sigma_e & & & & 35437 & & \\
\hline rho & & & 436 & of vari & i) & \\
\hline
\end{tabular}

\section{(Command: xtreg ROA SDR LDR FATA TDTELT SIZE, fe robust)}

Fixed-effects (within) regression Group variable: firm1

R-sq:

within $=0.4683$

between $=0.4742$

overall $=0.4651$

$\mathrm{F}(5,27)=197.28$

corr $\left(u_{-}, \mathrm{i}, \mathrm{Xb}\right)=0.1497$

$\begin{array}{lc}\text { Number of obs }= & 196 \\ \text { Number of groups }= & 28 \\ \text { Obs per group } & \\ \min = & 7 \\ \operatorname{avg}= & 7.0 \\ \max = & 7 \\ \text { Prob }>\mathrm{F}=\quad 0.0000\end{array}$

(Std. Err. adjusted for 28 clusters in firm1)

\begin{tabular}{|c|c|c|c|c|c|c|}
\hline \multirow{3}{*}{$\begin{array}{c}\text { ROA } \\
\text { SDR }\end{array}$} & \multicolumn{3}{|c|}{ Robust } & \multirow[b]{2}{*}{$\mathbf{P}>|\mathbf{t}|$} & \multirow{2}{*}{\multicolumn{2}{|c|}{ [95\% Conf. Interval] }} \\
\hline & Coef. & Std. Err. & $\mathbf{t}$ & & & \\
\hline & -.2575729 & .0310391 & -8.30 & 0.000 & -.320652 & -.1944938 \\
\hline LDR & -.2916491 & .046469 & -6.28 & 0.000 & -.3860783 & -.1972054 \\
\hline FATA & -.1175987 & .0612635 & -1.92 & 0.063 & -.2421011 & .0069038 \\
\hline TDTELT & .0245643 & .0038555 & 6.37 & 0.000 & .0167289 & .0323997 \\
\hline SIZE & .0050401 & .0137663 & 0.37 & 0.717 & -.0229365 & .0330167 \\
\hline _cons & .2103563 & .1030976 & 2.04 & 0.049 & .0008367 & .4198758 \\
\hline sigma_u & \multicolumn{6}{|c|}{.06424692} \\
\hline sigma_e & \multicolumn{6}{|c|}{.05947044} \\
\hline rho & \multicolumn{6}{|c|}{.53855049 (fraction of variance due to $\mathrm{u} \_\mathrm{i}$ ) } \\
\hline
\end{tabular}

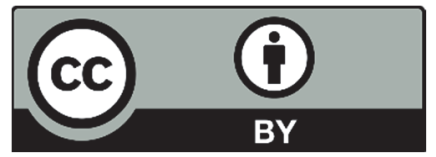

(C) 2020 by the authors; licensee Growing Science, Canada. This is an open access article distributed under the terms and conditions of the Creative Commons Attribution (CC-BY) license (http://creativecommons.org/licenses/by/4.0/). 